\title{
Predicting the probability of recession in Croatia: Is economic sentiment the missing link ${ }^{* 1}$
}

\author{
Nataša Erjavec ${ }^{2}$, Petar Sorić ${ }^{3}$, Mirjana Čižmešija ${ }^{4}$
}

\begin{abstract}
This paper aims to assess the possibility of predicting Croatian recessionary episodes using probit models. The authors first estimate a baseline static model using four leading indicators of recession (monetary base, unemployment, industrial production, and CROBEX stock market index). Lag lengths of up to 6 months are examined for each of the observed variables in the probit specification, and several important conclusions arise from the estimated models. First, the stock market and money supply exhibit the most pronounced leading characteristics in the Croatian economy (a 3-month lag length is selected by the information criteria). Second, the dynamic model (including a lagged dependent dummy variable) significantly outperforms the baseline static model. Third, the authors augment the probit model by the Economic Sentiment Indicator, which significantly contributes to the model accuracy. The latter confirms the main hypothesis of the paper, going in line with the assertion that psychological factors largely govern the economic cycles, growing in significance in times of economic hardship.
\end{abstract}

Key words: recession forecasting, probit regression, Economic Sentiment Index, Business and Consumer Surveys

JEL classification: $C 22, C 53$, E32, E60

\footnotetext{
* Received: 14-07-2016; accepted: 09-12-2016

1 This work has been fully supported by the Croatian Science Foundation under the project No. 3858.

${ }^{2}$ Full Professor, Faculty of Economics and Business, University of Zagreb, Trg J. F. Kennedy 6, Zagreb, Croatia. Scientific affiliation: time series analysis, econometrics. Phone: +3851 238 3360. Fax: +3851233 5633.E-mail: nerjavec@efzg.hr. Personal website: www.efzg.hr/ nerjavec (corresponding author).

${ }^{3}$ Assistant Professor, Faculty of Economics and Business, University of Zagreb, Trg J. F. Kennedy 6, Zagreb, Croatia. Scientific affiliation: nonlinear time series analysis, Business and Consumer Surveys. Phone: +3851238 3367.Fax:+3851233 3367.E-mail: psoric@efzg.hr. Personal website: www.efzg.hr/psoric.

${ }^{4}$ Full Professor, Faculty of Economics and Business, University of Zagreb, Trg J. F. Kennedy 6, Zagreb, Croatia. Scientific affiliation: business forecasting, Business and Consumer Surveys. Phone: +3851238 3304. Fax: +3851233 3304. E-mail: mcizmesija@efzg.hr. Personal website: www.efzg.hr/mcizmesija.
} 


\section{Introduction}

In assessing economic cycles, researchers have resorted to various methodological and empirical approaches. Numerous studies have made the effort to apply formal econometric forecasting tools such as the dynamic factor models (e.g. Kim and Nelson, 1998), to build coincident or leading indicators of the national economy (e.g. Stock and Watson; 1989 and 1993), or to identify the business cycle turning points (e.g. Bry and Boschan, 1971 or Pagan and Harding, 2002). This paper is concerned with one particular strand of research in that context: predicting the probability of recession using probit models. The rationale for focusing on predicting the recession (instead on the growth phase) is quite straightforward: a timely and efficient signal of incoming recession gives the economic policyholders an adequate amount of time to adopt specific anticyclical measures and structural changes in the national economy. Therefore, this paper aims to assess the possibility of predicting the recessionary episodes of the Croatian economic cycles by assessing four distinct leading indicators in a probit framework. The baseline model includes the monetary aggregate M1, unemployment rate, industrial production and the CROBEX stock market index.

The authors aim to provide answers to two research questions. First, does the dynamic specification of the probit model generate better fit in comparison to the static baseline model? Second, there is a quite voluminous literature on the accentuated role of psychological factors in governing economic crisis. The effect itself is thoroughly explained through the well-known "animal spirits" paradigm (Keynes, 1936), and it has recently experienced a strong revival in explaining the cause-and-effect chain in the Great Recession of 2008 (Kindleberger and Aliber, 2011). It is well established in the theoretical literature that economic agents, when faced with rising uncertainty in the system, lower their economic activity through various behavior patterns such as the "wait and see" strategy (Eberly, 1994) or precautionary savings (Carroll, 1992). Uncertainty also stimulates the inaction of firms by temporarily pausing the process of investing and hiring (Bloom, 2009). In that context, the authors argue that the inclusion of "psychological" factors in the model increases the accuracy of predicting recessions. In order to test this hypothesis, the authors employ the Economic Sentiment Indicator (ESI) as a "catch all" variable for the prevailing psychological conditions in the economic system. ESI is used in the empirical studies quite often (e.g. Gelper and Croux, 2010 or Sorić et al., 2013).

Therefore, the main hypothesis of the paper is that ESI raises the accuracy of probit models in forecasting recessions (compared to the baseline models comprising macroeconomic fundamentals).

The contribution of this paper is manifold. First, it offers a pioneer effort to predict the probability of Croatian recessionary developments using probit modelling. The Croatian literature has mostly been silent on that issue insofar. Second, it offers 
a comparative sectoral analysis, identifying the main economic sectors with the most pronounced "leading characteristics", i.e. predictive ability with regards to the overall economic activity. Third, in line with recent developments (Karnizova and Li, 2014), this study acknowledges the importance of psychological factors in governing the economic cycle. To account for that, ESI is utilized to quantify the prevailing economic sentiment in the national economic system, and its predictive ability is compared to the one of standard macroeconomic fundamentals.

The paper is structured as follows. Section 2 summarizes the main findings of relevant international studies on probit-based forecasting models. Section 3 briefly discusses the utilized data set, the applied methodology for identifying the business cycle turning points, the procedure of collecting and quantifying Business and Consumer surveys data and the basic setting of the examined probit models. Section 4 introduces the utilized estimation strategy. Section 5 discusses the obtained empirical results, while the final part concludes the paper by introducing its policy implications and recommendations for future research.

\section{Literature review}

The issue of predicting the turning points of national business cycles has always been the focal point of macroeconomic research. Some of the early efforts (and also the most influential studies of this kind) were done by Estrella and Mishkin (1998), and Bernard and Gerlach (1998).

Estrella and Mishkin (1998) establish a quarterly probit model of US recessions, using as much as 27 regressors, divided into five groups: interest rates and spreads, stock prices, monetary aggregates, individual macro indicators and leading indicators. Their probit forecasts corroborate that the interest rate spread (difference between 10 year and 3-months Treasury rate) is by far the best recessionary predictor. Among other variables, the monetary base, stock prices and the Stock and Watson $(1989,1993)$ leading index significantly add to the prediction accuracy. However, the overall conclusion is that the predictions perform reasonably well only for shorter forecasting horizons (one to two quarters ahead).

Bernard and Gerlach (1998) extend the work of Estrella and Mishkin (1998) by estimating probit models for Belgium, Canada, France, Germany, Japan, the Netherlands, the UK and the US. They find that the interest rate spreads significantly enter the probit equations for all examined countries. Also importantly, they find that the foreign (German and US) spreads significantly add to the predictions in all countries except Japan and the UK.

Among the more recent empirical studies, one should certainly mention Nyberg (2010), who applied a dynamic probit model to forecast the recession periods in 
the US and Germany. Following on previous studies, Nyberg (2010) also applies the interest rate spread (difference between 10 year and 3-months interest rates) as an explanatory variable, finding it to be the most valuable recession predictor. Apart from that, the stock market returns also prove to be significant, as well as the foreign term spread. These results hold for both examined countries.

Instead of searching for the "optimal" recession predictors, Chen et al. (2011) extend the popular probit methodology by applying dynamic factor modelling on as much as 141 financial and macroeconomic time series. They find that their modelling strategy outperforms the benchmark probit models with some of the standard US leading indicators.

$\mathrm{Ng}$ (2012) differentiates between four separate financial and macroeconomic risk factors, all of which are then examined as US recession predictors in various probit models. The first factor (financial market expectations) is quantified by the standard short- and long-term interest rate spread. The second factor refers to credit and liquidity risk, and is captured as the difference between the 3-month LIBOR and 3 -month Treasury bill rate. The risk of negative wealth effect is proxied by stock market returns, while the risk of deteriorating macroeconomic fundamentals are captured by eight different leading indicators for the US economy. The vast majority of the stated factors turn out to be highly significant in static probit equations, so the authors concentrate on comparing the predictive accuracy of static vs. dynamic probit models. The results mostly confirm the dominance of the dynamic model specification.

All paper cited up to this point unanimously point to the dominant role of financial variables (primarily the interest rate spread) in explaining and forecasting business cycles. However, there is also strong evidence that the economic cycles are to some extent under the influence of psychological factors such as economic sentiment or economic uncertainty. Karnizova and Li (2014) estimate a probit model of US recessions with standard explanatory variables: interest rate spreads, stock market returns and stock market volatility. They make a solid contribution by adding an insofar mostly neglected psychological factor: economic uncertainty quantified by Baker et al. (2016). The empirical results obtained by Karnizova and $\mathrm{Li}$ (2014) seem remarkable: economic uncertainty outperforms each of the analyzed predictors (including the term spread) at horizons longer than five quarters.

The conclusions drawn from the above mentioned studies can be summed up to four points. Firstly, the vast majority of these papers are concentrated on the US economy. The only exception in that sense is the study of Bernard and Gerlach (1998), but they also estimate the probit model only for highly developed world countries. This conditions the prevailing usage of interest rates and spreads as explanatory variables. However, the US official statistics are abundant with financial data, which other countries such as Croatia do not measure or do not regularly publish on a monthly 
basis. For example, the 10-year interest rate is not recognized by the Croatian monetary system, although it is widely used in the USA (and consequentially employed by Estrella and Mishkin (1998), Bernard and Gerlach (1998), Nyberg (2010), Ng (2012) and Karnizova and Li (2014) for calculating the interest rate spread. Also, it is well-established in the literature that the interest rate channel of the Croatian monetary transmission mechanism is completely inactive (Erjavec and Cota, 2003 and Vizek, 2007) Therefore, this paper aims to provide fresh evidence on the predictability of Croatian recessions using the money stock as the representative of the monetary sector (instead of the interest rate spread). ${ }^{5}$

Secondly, the lag structure of explanatory variables is to some extent neglected in the literature. For example, Estrella and Mishkin (1998) arbitrarily impose lags of certain regressors in order to align their publication times. This paper adds to the literature by examining up to 6 lags of each regressor, and estimating the probit equation with the best fitting lag order. In that context, the third relevant point would be the vastly proven dominance of dynamic versus static probit models (Nyberg, 2010; Ng, 2012). It would therefore be interesting to explore whether the same conclusion can be derived from this study. Finally, Karnizova and Li (2014) add a new dimension to this strand of literature by examining the predictive accuracy of a psychological factor. Since the Baker et al. (2016) economic policy uncertainty index (or any other similar uncertainty indicator) does not exist for Croatia; the authors utilize ESI as a proxy variable and question its significance in predicting the Croatian recessions.

\section{Methodology}

This section briefly introduces the utilized methodological framework for dating the business cycle turning points, as well as their prediction using probit regressions.

\subsection{Dating the business peaks and troughs}

Proper identification of business cycle turning points is a prerequisite for predicting recessions. In accordance with the relevant international literature, the Bry and Boschan (1971) algorithm is applied here for the identification of peaks and troughs of aggregate Croatian economic activity. First, a question of finding the appropriate proxy variable for economic activity arises. Since GDP is published quarterly, it does not enable a sufficiently high data frequency for a timely indication of a shift from one particular cycle phase to another one. To resolve that issue, the seasonally adjusted industrial production index $(I N D, 2010=100)$ is examined as the aggregate

\footnotetext{
5 Detailed description of the entire employed data set can be found in Table A1 in Appendix.
} 
output proxy (for more details on the examined dataset see section 4). This is by no means a novelty in empirical macroeconomic research (e.g. Vizek (2007), Erjavec et al. (2012) or Cunado and Perez de Garcia (2005) use the same approximation). The Bry and Boschan (1971) procedure is applied in the time period of $2000 \mathrm{M} 01$ to 2015 M12 (see Table A1 in Appendix) for detailed time spans of all the observed variables, along with their basic descriptive statistics).

The procedure of dating peaks and troughs is based on the following:

peak at time $t$ if the value of industrial production at time $t$ (INDt) satisfies the relation

$$
I N D_{t-k}, \ldots, I N D_{t-2}, I N D_{t-1}<I N D_{t}<I N D_{t+1}, I N D_{t+2}, \ldots, I N D_{t+k}, k \geq 5
$$

trough at time $t$ if the value of industrial production at time $t\left(\mathrm{IND}_{t}\right)$ satisfies the relation

$$
I N D_{t-k}, \ldots, I N D_{t-2}, I N D_{t-1}>I N D_{t}>I N D_{t+1}, I N D_{t+2}, \ldots, I N D_{t+k} . k \geq 5
$$

A peak is identified for the largest possible $k$ that satisfies relation (1), while a trough is identified for the largest possible $k$ that satisfies relation (2).

The algorithm applies certain censoring rules to satisfy two important conditions. First, each business cycle phase (recession or expansion) must last at least 5 months ( $k$ should be minimally equal to 5 ). Second, the full cycle (peak to peak and trough to trough) must have a minimum duration of 15 months. The algorithm is applied in RATS software.

\subsection{Probit regression model}

The dependent variable in the probit regression model is a recession indicator that takes on value one if the economy is in recession, and value zero if the economy is in an expansionary state at time $t$, i.e.:

$$
Y_{t}= \begin{cases}1, & \text { if economy is in a recession at time } t \\ 0, & \text { if economy is not in a recession at time } t\end{cases}
$$

Conditional on the information set $\Omega_{t-1}$ at time $t-1, Y_{t}$ has a Bernoulli distribution:

$$
Y_{t} \mid \Omega_{t-1} \sim B\left(p_{t}\right) .
$$

If $E_{t-1}(\cdot)$ and $P_{t-1}(\cdot)$ denote the conditional expectation and probability given the information set $\Omega_{t-1}$ at time $t-1$ (respectively), the conditional expectation of $Y_{t}$ can be specified as

$$
E_{t-1}\left(Y_{t}\right)=P_{t-1}\left(Y_{t}=1\right)=p_{t}=\Phi\left(\pi_{t}\right)
$$


where $\pi_{t}$ is a linear function of variables included in the information set $\Omega_{t-1}$ and $\Phi(\cdot)$ is a standard normal cumulative distribution function.

In the standard static probit model that quantifies recession probabilities, a linear function of explanatory variables $\left(\pi_{t}\right)$ is defined as

$$
\pi_{t}=\alpha+X_{t-k} \beta,
$$

where $X_{t-k}$ is a matrix of independent (explanatory) variables available in time $t-k$, with the corresponding coefficient vector $\beta$.

Thus, the probability of recession at time $t$ is predicted at time $t-1$, using the set of information on predictor variables $X_{t-k}$ at time $t-k$. The time lag $k$ can be different for different predictive variables.

The parameters of the probit model are estimated by maximizing the following loglikelihood function.

$$
\log L(Y, \alpha, \beta)=\sum_{t=1}^{n}\left[Y_{t} \log \Phi\left(\alpha+X_{\mathrm{t}-\mathrm{k}} \beta\right)+\left(1-Y_{t}\right) \log \left(1-\Phi\left(\alpha+\mathrm{X}_{\mathrm{t}-\mathrm{k}} \beta\right)\right)\right]
$$

To correct for potential misspecification errors, Huber-White robust standard errors are used for inference purposes.

The empirical analysis of this paper follows a step-wise procedure. First, the optimal static probit model is found for the Croatian economy. The selection of the best predictive static model for the state of Croatian economy is based on McFadden's Adjusted-pseudo- $\mathrm{R}^{2}$ (Estrella, 1998) and Bayesian information criteria (BIC). ${ }^{6}$ Additionally, for each model the values of some other measures of model fit are considered, such as the percentage of correct prediction of recession, the percentage of correct prediction of non-recession (expansion), the percentage of overall correct prediction of both recession and non-recession months. After selecting the best static model for forecasting the probability of recession in Croatia, the model was extended by adding a lagged value of the dependent variable as an additional predictor, i.e. a dynamic model was estimated:

$$
\pi_{t}=\alpha+X_{t-k} \beta+\delta Y_{t-1}
$$

The dynamic model eliminates the shortcomings of the static model by accounting for the dynamic structure of the binary dependent variable. Including the information contained in the autocorrelation structure of the dependent variable $Y_{t-1}$ improves the

\footnotetext{
${ }^{6}$ In the empirical analysis, model selection criteria and pseudo R2 are commonly used measures to assess the fit of a probit model (selection of optimal lag lengths) and to compare competing models (see e.g. Estrella and Mishkin, 1998; Kauppi and Saikkonen, 2008 or Ng, 2012).
} 
prediction of recession probability and accounts for potential model misspecification (Dueker, 1997; Moneta, 2005).

\subsection{Economic Sentiment Indicator}

Economic Sentiment Indicator (ESI) is a composite indicator derived from the Business and Consumer surveys (BCS). BCS are harmonized monthly surveys on the EU level, providing managers' and consumers' judgments about the past, present and future tendencies of key economic variables. In essence, BCS are of qualitative nature, but managers' and consumers' answers are commonly translated into numerically expressed indicators.

With the aim to fully synchronize BCS on the EU level, the European Commission has defined The Joint Harmonized EU Programme of Business and Consumer Surveys. This programme was launched by the European Commission decision of 15 November 1961, and was modified through the subsequent Council and Commission decisions. It was last approved through the Commission decision C(97) 2241 of 15 July 1997 and presented in the Commission communication COM(2006) 379 of 12 July 2006 (European Commission, 2016).

This document regulates and unifies the methodology of conducting BCS, which enables direct comparability of their results among various EU members. The surveys are carried out on a regular monthly basis in five sectors of each country: the industrial sector, retail trade, construction, services and the consumer sector. The first survey was the harmonized business survey in the manufacturing industry, conducted in 1962. Then, the BCS programme was extended to the construction sector and to investment plans in the manufacturing sector in 1966, to consumers in 1972, to the retail trade in 1984, and to the services sector in 1996. Since 2007, the Commission conducts a survey in the financial services sector at EU and euro-area level.

The Joint Harmonized EU Programme now (July 2016) includes all 28 EU Member States, as well as five candidate countries: Albania, Montenegro, The Former Yugoslav Republic of Macedonia, Turkey and Serbia.

Answers obtained from the surveys are aggregated in the form of "balances"7. Balances are differences between the percentages of respondents giving positive and negative replies. Seasonally adjusted balances are used to calculate the composite indicators in five sectors: manufacturing industry, services, construction and retail trade, as well as for consumers. For all of these five sectors, individual

\footnotetext{
7 Methodological considerations can be found in the European Commission special report No. 5/2006, in the Joint Harmonized EU Programme of Business and Consumer Surveys, available at: http://ec.europa.eu/economy_finance/db_indicators/surveys/documents/studies/ee_bcs_2006_05_en.pdf. $\mathrm{http} / / /$ ec.europa.eu/economy_finance/db_indicators/surveys/documents/bcs_user_guide_en.pdf.
} 
confidence indicators are calculated as simple arithmetic averages of the (seasonally adjusted) balances (in percentage points) of answers to the selected questions in surveyed sectors. The industrial confidence indicator (ICI) includes three variables: production expectations, order books and stocks of finished products (the last with an inverted sign). The services confidence indicator (SCI) comprises the business climate, recent and expected evolution of demand. The consumer confidence indicator (CCI) includes four variables: the financial situation of households, the general economic situation, unemployment expectations (with an inverted sign) and savings, all over the next 12 months. The retail trade confidence indicator (RTCI) comprises the present and future business situation and stocks (the last with inverted sign). The construction (building) confidence indicator (BCI) includes two variables: order books and employment expectations.

ESI components are 15 variables $\left(x_{j}\right)$ included in five individual confidence indicators (as indicated above). Variables of stocks of finished products, unemployment expectations and stocks in retail trade are inversely correlated with the reference series (GDP). Therefore they are included in ESI calculation with an inverted sign. The selection of questions was conducted with the aim of achieving the highest coincident correlation of the confidence indicator with the reference series (for example: year-on-year growth of industrial production).

The EU harmonized methodology of calculating ESI includes five steps, and is presented as follows (Lolić et al., 2015). ESI components (seasonally adjusted balances) are weighted as follows: industry 0.4 ; services 0.3 ; consumers 0.2 ; construction 0.05 and retail trade 0.05, (European Commission, 2016). The weights have been determined by the European Commission, according to the "representativeness" of the sector in question and its tracking performance visà-vis GDP as a reference variable. These weights are applied to the standardized individual variables components $\left(y_{j}\right)$. The standardization is conducted over a frozen sample to avoid monthly revisions of the index, as in (9) and (10).

$$
\begin{aligned}
& y_{j, t}=\frac{x_{j, t}-\bar{x}_{j}}{s_{j}} ; \forall j=1,2, \ldots, 15 ; t=1,2, \ldots, n \\
& \bar{x}_{j}=\frac{1}{T^{\prime}} \sum_{t=1}^{T^{\prime}} x_{j, t} ; s_{j}=\sqrt{\frac{1}{T^{\prime}-1} \sum_{t=1}^{T^{\prime}}\left(x_{j, t}-\bar{x}_{j}\right)^{2}},
\end{aligned}
$$

where $T^{\prime}$ is a number of observations in the frozen sample (period). European Commission defines the frozen period for all EU member states as January 1990 December 2013 (when applicable). For Croatia, the conduction of consumer surveys starts with May 2005, and all other series start with May 2008. Therefore, in Croatia $T^{\prime}=116$ for the consumer survey data and $T^{\prime}=80$ for all other sectors. The weighted average $z_{t}$ of individual standardized response balances is then calculated, as in (11). 


$$
z_{t}=\frac{\sum_{j=1}^{15} w_{j} \cdot y_{j, t}}{\left(\sum_{j=1}^{15} w_{j}\right)_{t}} ; t=1,2, \ldots, n
$$

where $\left(\sum_{j=1}^{15} w_{j}\right)_{t}$ is the sum of weights of the available series at time $t$.

The weighted average $z_{t}$ is then scaled to have a long-term mean of 100 and a standard deviation of 10, as in (12) and in (13).

$$
\begin{aligned}
& E S I_{t}=\left(\frac{z_{t}-\bar{z}}{s_{z}}\right) \cdot 10+100 ; t=1,2, \ldots, n \\
& \bar{z}=\frac{1}{T^{\prime}} \sum_{t=1}^{T^{\prime}} z_{t}, \quad S_{z}=\sqrt{\frac{1}{T^{\prime}-1} \sum_{t=1}^{T^{\prime}}\left(z_{t}-\bar{z}\right)^{2}}
\end{aligned}
$$

The interpretation of ESI is as follows: if the value of ESI exceeds 100, the economic sentiment in the national economy is above average, and if ESI is less than 100, the economic sentiment is below average. With the assumption of approximate normality, for the standard deviation of 10 (and expected value 100), $68 \%$ of the ESI values lie between 90 and 110 and about $95 \%$ of the ESI values are between 80 and 120 .

ESI is defined and empirically confirmed as a leading indicator used in predicting the changes of GDP, industrial production, employment, private consumption, stock market changes, etc. The predictive power of sentiment surveys, especially ESI, is addressed in numerous studies: Gajewski (2014), Altin and Uysal (2014), Gelper and Croux (2010), Martinakova and Kapounek (2013), Pošta and Pikhart (2012).

ESI can provide a wealth of information for macroeconomic policy formulation and analysis. Van Aarle and Kappler (2012) integrate the EU ESI data into an econometric analysis of the euro area business cycle and suggest that sentiment shocks do have an impact on important macroeconomic variables such as output, retail sales, and unemployment.

Subeniotis et al. (2011) investigated how inflation, market capitalization, industrial production and ESI affect the EU-12 stock markets. Zanin (2010) explored the relationship between changes in the Economic Sentiment Indicator and real GDP growth. 
Adamowicz and Walczyk (2013) analyzed the relationship between confidence indicators (ICI, BCI, RTCI, CCI and ESI) on one side and the main macroeconomic variables such as GDP, private consumption, industrial production, construction production and retail sales on the other side for the recession period. The results indicate that the crisis is deeply embedded in the heads of economic agents. A strong fear of the future is expressed in their pessimistic sentiments.

With that in mind, this paper aims to augment the baseline probit models for predicting the probability of Croatian recession with ESI data. That way the predictive characteristics of Croatian ESI will be formally econometrically tested.

\section{Empirical data and analysis}

The baseline probit model includes the following monthly variables: industrial production index (IND, 2010=100), monetary aggregate M1 (ln-transformed, LM1), stock market CROBEX index (STOCK), and unemployment rate (U). This model is afterwards augmented by ESI to find out if it possesses any added value in comparison to the baseline model. All variables are seasonally adjusted using the ARIMA X12 method. Time spans and data sources for all variables are presented in Table A1 in Appendix.

The Bry and Boschan (1971) algorithm has detected three recessionary episodes in the Croatian industrial production. The first recession was recognized in the period of 2002 M04 to 2003 M03. The second one spans from 2004 M03 to 2006 M04, while the last one refers to the recent global crisis: 2008 M07 to 2014 M11. Therefore, the recession indicator variable $Y_{t}$ takes on the value of one within the three stated periods, and the value of zero for all other monthly observations.

This paper employs the following empirical estimation strategy. The initial step is to find the optimal static model for predicting the probability of recession in Croatia with four recession predictors (IND, LMI, STOCK, and $U$ ). The performances of different probit models are analyzed, experimenting with different lags of explanatory variables. Upon establishing the optimal static model, ESI is added to the model specification in order to question its predictive ability. Finally, the selected static model is augmented by including the lagged dependent variable as an additional predictor (equation 8) to compare the forecasting accuracy of the static and dynamic version of the model.

In order to obtain the optimal static probit models (equation 6) employing variables $I N D, L M 1, S T O C K$, and $U$, all four predictors are examined with various lag lengths. Firstly, the models were estimated with only one explanatory variable and different lag lengths (from one to six) at a time for each of the four predictors. The obtained results are presented in Table A2 in Appendix. Based on the highest pseudo 
$\mathrm{R}^{2}$ and the smallest BIC value, the optimal model includes the first lag of IND, the fourth lag of STOCK and the sixth lag of variables LM1 and U. This means that monetary aggregate and unemployment possess the most pronounced leading characteristics with regards to predicting recessions. However, this conclusion stems from univariate probit models, so it was crucial to inspect whether the same applies also for the multivariate case.

To account for that, we estimated models that include the same number of lags for all predictors (from one to three) ${ }^{8}$ and compared the fit of such models with the optimal models from Table A2 in Appendix. The results are summarized in Table 1. In all models, the coefficients have the expected signs and are statistically significant, except for the industrial production in the model with three lags. On the basis of Table 1, it seems that the optimal fit is obtained for the case of 3 monthly lags for all variables. However, it turns out that industrial production has a nonsignificant effect here. Since one of the aims of this study is to assess the predictive ability of ESI, the authors focused on finding the optimal specification of the multivariate static probit model (that includes ESI), and compare its accuracy to the one of Model 3 in Table 1.

Table 1: Estimation results for the static model with the same number of lags for all predictors

\begin{tabular}{|l|r|r|r|}
\hline \multirow{2}{*}{ Predictors } & Model 1 & \multicolumn{1}{c|}{ Model 2 } & \multicolumn{1}{c|}{ Model 3 } \\
\cline { 2 - 4 } & $\mathrm{k}=1$ (for all variables) & $\mathrm{k}=2$ (for all variables) & $\mathrm{k}=3$ (for all variables) \\
\hline IND & $-0.0636^{* *}$ & $-0.0632^{* *}$ & -0.0433 \\
\hline LM1 & $-22.6252^{* * *}$ & $-23.8122^{* * *}$ & $-28.8817^{* * *}$ \\
\hline STOCK & -0.0017 & $-0.0021^{*}$ & $-0.0030^{* *}$ \\
\hline U & -0.2640 & -0.4216 & $-0.5386^{*}$ \\
\hline \multicolumn{4}{|c|}{ Measures of model fit } \\
\hline BIC & 46.6805 & 47.4228 & 43.4750 \\
\hline Pseudo R ${ }^{2}$ & 0.7187 & 0.7101 & 0.7563 \\
\hline Adjusted pseudo $\mathrm{R}^{2}$ & 0.6016 & 0.5930 & 0.6392 \\
\hline Log likelihood & -12.0088 & -12.3799 & -10.4060 \\
\hline chi2 & 34.4416 & 34.4314 & 27.8123 \\
\hline
\end{tabular}

Note: Huber-White robust standard errors. Estimate of a constant is not reported. ${ }^{*} \mathrm{p}<.1 ;{ }^{* *} \mathrm{p}<.05 ;{ }^{* * *} \mathrm{p}<.01$.

Source: Authors' calculation

8 Inclusion of more than three lags results in models with no significant variables, which is probably due to the small sample size. 
According to the model fit statistics ${ }^{9}$, the best model includes the second lag of ESI and the third lags of all other predictors (see Table A3 to Table A5 in Appendix). The results are presented in Table 2. Since variables industrial production and unemployment are not significant, they are excluded from the final estimation of the "optimal" static and dynamic in-sample models for predicting the probability that the Croatian economy is in a recession state.

We then extended the selected static model by including the lagged dependent variable as an additional predictor, i.e. we estimated the dynamic model (equation 8). The results are presented in the final column of Table 2.

Table 2: Estimation results for the selected optimal static and dynamic models with ESI in predicting the probability of Croatian recession

\begin{tabular}{|l|r|r|}
\hline \multicolumn{1}{|c|}{ Predictors } & Optimal static model & Optimal dynamic model \\
\hline ESI $_{\mathrm{t}-2}$ & $-0.0295^{* * *}$ & $-0.0483^{* *}$ \\
\hline LM $_{\mathrm{t}-3}$ & $-34.6782^{* * *}$ & $-40.0930^{* * *}$ \\
\hline STOCK $_{\mathrm{t}-3}$ & $-0.0019^{* * *}$ & $-0.0010^{*}$ \\
\hline $\mathrm{Y}_{\mathrm{t}-1}$ & $4.0634^{* * *}$ \\
\hline Measures of model fit & 36.9182 & 28.5031 \\
\hline BIC & 0.7800 & 0.9316 \\
\hline Pseudo R & \\
\hline Adjusted pseudo R & 0.6863 & 0.8145 \\
\hline Log likelihood & -9.3939 & -2.9200 \\
\hline chi2 & 11.2208 & 57.1445 \\
\hline
\end{tabular}

Note: Huber-White robust standard errors. Estimate of a constant is not reported.

$$
{ }^{*} \mathrm{p}<.1 ;{ }^{* *} \mathrm{p}<.05 ;{ }^{* * *} \mathrm{p}<.01 \text {. }
$$

Source: Authors' calculation

Table 2 summarizes the obtained results for the static and dynamic models. All coefficients have the expected sign. The coefficient of the lagged recession indicator is significantly positive in the dynamic model, indicating the importance of previous states of the economy in recession prediction, i.e. dealing with the potential autocorrelation structure of the dependent variable.

For assessing the predictive power of each model to identify a recession month, we additionally calculated the percentage of correct prediction of recession months,

\footnotetext{
$\overline{9}$ For assessing the predictive power of each model we also consider the other statistics, such as the percentage of correct prediction of recession, the percentage of correct prediction of non-recession, the percentage of overall correct prediction of both recession and non-recession months as well as the root-mean-square error and come to the same conclusion.
} 
the percentage of correct prediction of non-recession months, and overall correct prediction of both recession and non-recession months using the thresholds of $50 \%$ and $25 \%$, respectively, as it can be seen in Table 3 .

Table 3: The percentage of correct prediction for thresholds 0.5 and 0.25

\begin{tabular}{|l|r|r|r|r|}
\hline \multirow{2}{*}{\multicolumn{2}{|c|}{ Statistics }} & \multicolumn{2}{|c|}{ Threshold 0.5} & \multicolumn{2}{c|}{ Threshold 0.25} \\
\cline { 2 - 5 } & Static & \multicolumn{1}{c|}{ Dynamic } & Static & \multicolumn{1}{c|}{ Dynamic } \\
\hline Correct recession prediction & $98.70 \%$ & $98.70 \%$ & $98.70 \%$ & $100.00 \%$ \\
\hline Correct non-recession prediction & $87.50 \%$ & $93.75 \%$ & $68.75 \%$ & $93.75 \%$ \\
\hline Correctly classified (overall) & $96.77 \%$ & $97.85 \%$ & $93.55 \%$ & $98.92 \%$ \\
\hline
\end{tabular}

Source: Authors' calculation

Statistics presented in Table 3 suggest that for both models the percentages of correct prediction (of recession, non-recession and overall) are very high despite the value of a threshold.

\section{Results and discussion}

The obtained results for the selected optimal static and dynamic models prove the utter dependence of Croatian economy on its financial and monetary sectors (Table 2 ). This comes as no surprise since the so-called direct monetary transmission (from money supply to real economic activity) is already firmly recognized in the empirical studies. For example, the causality from monetary aggregate M1 to aggregate economic activity is also found by Erjavec and Cota (2003) and Vizek (2007). As far as the financial sector is concerned, the existing studies mostly neglect the interdependence of the Croatian stock market and overall economic activity. Tomić and Sesar (2015) perform one of the rare studies of causality between the two variables of interest, finding causality from the industrial production to CROBEX, but not the other way round. Therefore, this study provides one of the first contributions in that context, finding a significant link between the financial market and aggregate economic activity.

Another important issue is the influence of psychological factors such as economic sentiment in governing the business cycle. Economic Sentiment Indicator (ESI) is found to significantly add to the predictions of the probability of Croatian economy being in the recession state. This speaks in favor of "psychologically driven" recessions. Although the economic sentiment is obviously not the central cause of recessions in Croatia, it is obviously able to explain a considerable portion of the complex recession puzzle. The intensity and endurance of the recent recession in Croatia is certainly partly owed to 
psychological factors such as contagion effects, herd-like behavior, as well as consumers', investors' and entrepreneurs' inaction due to the growing uncertainty in the system. High significance of ESI is also found in similar studies of the Croatian economy (Čižmešija and Sorić, 2010).

Estimation results for the dynamic model (Table 2) point out the importance of previous states of the economy in recession prediction. The results also show that dynamic probit model outperforms the standard static model, and that the lagged recession indicator is an important predictor of future recessions in Croatia. One should also notice that the influence of ESI is approximately twice as large when the dynamics of the model is accounted for.

As for the predictive power of each model to identify the recession months in Croatia, the results of correct prediction are very high for both models (static and dynamic). However, based on the reported values of the percentage of correct prediction of recession months, the percentage of correct prediction of non-recession months, and overall correct prediction of both recession and nonrecession months using the thresholds of $50 \%$ and $25 \%$, the dynamic probit model slightly outperforms the static one (Table 3). For example, using the threshold value of 0.5 to classify a recession month, both models generate $98.70 \%$ correct prediction. On the other hand, the dynamic model generates $93.75 \%$ correct prediction of non-recession month compared to static model with $87.50 \%$. The percentage of correct overall classification for dynamic model of $97.85 \%$ is higher compared to static of $96.77 \%$. Using the lower threshold value does not improve the ability of the models to predict recession significantly. Although, using the threshold value of 0.25 improves the percentage of correct prediction of recession months for dynamic probit model, as well as the percentage of overall correct prediction, for a static model the use of a lower value of a threshold decrease the ability to predict non-recession months. Therefore, using the standard value of 0.5 as a threshold values shows to be adequate for both models. Once more, the obtained results confirm our conclusion that the dynamic probit model slightly outperforms the static probit models in predicting the recession periods in Croatia.

\section{Conclusion}

Estimation results of both static and dynamic models confirm the working hypothesis that adding the Economic Sentiment Indicator to the baseline probit model (including unemployment, monetary aggregate M1, CROBEX stock market index, and industrial production) significantly improves the model accuracy in forecasting recessions. In addition, the results reveal that the dynamic probit model specification provides considerably more accurate results than the static 
specification. This paper represents a pioneer effort to predict the probability of Croatian recessions using probit models. Since this is, to the best of the authors' knowledge, the first empirical estimation of a dynamic probit model in the context of predicting Croatian recessionary episodes, it constitutes a substantial contribution to the economic science. The most pronounced limitation of this study is that it employs industrial production as a monthly proxy indicator of economic activity. Future research should certainty involve more advanced temporal disaggregation techniques, that might lead to efficient estimates of monthly GDP in Croatia. The main implication of the obtained results of the estimated probit models for economic and development policy in Croatia is the ability of monitoring and stabilizing the economic sentiment as a psychological determinant of business cycles. Any kind of reform (fiscal, monetary or purely administrative) and its underlying measures should be properly communicated to all interested parties, with precisely defined schedules, time frames, and expected outcomes. That way the economic uncertainty in the system can be held under control, without boosting its possible negative effects on the aggregate economic activity. Therefore, inclusion of the Economic Sentiment Indicator (which express the psychological characteristics of economic agents) in econometric models, enables more precise tracking, explaining and predicting changes in the national economy.

\section{References}

Adamowicz, E., Walczyk, K. (2013) "New EU countries after the great recession", Transformations in business \& economics, Vol. 12, No. 2B, pp. 255-265.

Altin, M., Uysal, M. (2014) "Economic sentiment indicator as a demand determinant", Tourism Analysis, Vol. 19, No. 5, pp. 581-597, doi: 10.3727/1083 $54214 X 14116690097855$.

Baker, S., Bloom, N., Davis, S. (2016) "Measuring economic policy uncertainty", The Quarterly Journal of Economics, (forthcoming), doi: 10.1093/qje/qjw024.

Bernard H., Gerlach S. (1998) "Does the term structure predict recessions? The international evidence", International Journal of Finance and Economics, Vol. 3, No. 3, pp. 195-215, doi: 10.1002/(sici)1099-1158(199807)3:3<195::aidijfe81>3.0.co;2-m.

Bloom, N. (2009) "The impact of uncertainty shocks", Econometrica, Vol. 77, No. 3, pp. 623-685, doi: 10.3982/ECTA6248.

Bry, G., Boschan, C. (1971) "Cyclical Analysis of Time Series: Selected Procedures and Computer Programs", National Bureau of Economic Research. New York.

Carroll, C.D. (1992) "The Buffer Stock Theory of Saving: Some Macroeconomic Evidence", Brooking Papers on Economic Activity, No. 2, pp. 61-155, doi: $10.2307 / 2534582$. 
Chen, Z., Iqbal, A., Lai, H. (2011) "Forecasting the probability of US recessions: a Probit and dynamic factor modelling approach", Canadian Journal of Economics, Vol. 44, No. 2, pp. 651-672, doi: 10.1111/j.1540-5982.2011.01648.x.

Cunado, J., Perez de Gracia, F. (2005) "Oil prices, economic activity and inflation: evidence for some Asian countries", The Quarterly Review of Economics and Finance, Vol. 45, No. 1, pp. 65-83, doi: 10.1016/j.qref.2004.02.003.

Čižmešija, M., Sorić, P. (2010) "Assessing Croatian GDP components via Economic Sentiment Indicator”, Economic Research, Vol. 23, No. 4, pp. 1-10, doi: 10.1080/1331677X.2010.11517429.

Dueker, M. (1997) "Strengthening the case for the yield curve as a predictor of US recessions", Federal Reserve Bank of St. Louis Economic Review, Vol. 79, No. 2, pp. 41-51.

Eberly, J. (1994) “Adjustment of Consumers' Durables Stocks: Evidence from Automobile Purchases", Journal of Political Economy, Vol. 102, No. 3, pp. 403-436.

Erjavec, N., Cota, B. (2003) "Macroeconomic Granger-causal dynamics in Croatia: Evidence based on a vector error-correction modelling analysis", Ekonomski pregled, Vol. 54, No. 1-2, pp. 139-156.

Erjavec, N., Cota, B., Jakšić, S. (2012) "Impact of macroeconomic shocks on real output fluctuations in Croatia", Zagreb International Review of Economics \& Business, Vol. SCI (Special Conference Issue), No. 1, pp. 69-78.

Estrella, A., Mishkin, F. S. (1998) "Predicting U.S. recessions: financial variables as leading indicators", Review of Economics and Statistics, Vol. 80, No.1, pp. 45-61, doi: 10.1162/003465398557320.

European Commission (2016) "The Joint Harmonised EU Programme of Business and Consumer Surveys - User Guide". Available at: <http://ec.europa.eu/ economy_finance/db_indicators/surveys/documents/bcs_user_guide_en.pdf $>$ [Accessed: July 12, 2016]

Gajewski, P. (2014) "Nowcasting Quarterly GDP Dynamics in the Euro Area - The Role of Sentiment Indicators", Comparative Economic Research, Vol. 17, No. 2, pp. 5-23, doi: 10.2478/cer-2014-0011.

Gelper, S., Croux, C. (2010) „On the construction of the European Economic Sentiment Indicator", Oxford Bulletin of Economics and Statistics, Vol. 72, No. 1, pp. 47-62, doi: 10.1111/j.1468-0084.2009.00574.x.

Karnizova, L., Li, J.C. (2014) "Economic policy uncertainty, financial markets and probability of US recessions", Economic Letters, Vol. 125, No. 2, pp. 261-265, doi: 10.1016/j.econlet.2014.09.018.

Kauppi, H., Saikkonen, P. (2008) "Predicting U.S. recessions with dynamic binary response models", Review of Economics and Statistics, Vol. 90, No. 4, pp. 777791, doi: 10.1162/rest.90.4.777. 
Keynes J.M. (1936) The General Theory of Employment, Interest, and Money, New York. Hartcourt, Brace.

Kim, C. J., Nelson, C. R. (1998) "Business cycle turning points, a new coincident index, and tests of duration dependence based on a dynamic factor model with regime switching", Review of Economics and Statistics, Vol. 80, No. 2, pp. 188-201, doi: 10.1162/003465398557447.

Kindleberger, C.P., Aliber, R.Z. (2011) Manias, Panics and Crashes: A history of financial crise, Palgrave Macmillan, UK.

Lolić, I., Sorić, P., Čižmešija, M. (2015) "Redifining the Croatian Economic Sentiment Indicator", International journal of Social, Behavioral, Education, Economic and Management Engineering, Vol. 9, No. 8, pp. 2337-2340.

Martinakova, R., Kapounek, S. (2013) "Economic sentiment indicator and its information capability in the Czech Republic", Acta Universitatis Agriculturae et Silviculturae Mendelianae Brunensis, Vol. 61, No. 7, pp. 2491-2498, doi: 10.11118/actaun201361072491.

Moneta, F. (2005) "Does the yield spread predict recessions in the euro area?" International Finance, Vol. 8, No. 2, pp. 263-301, doi: 10.1111/j.14682362.2005.00159.x.

Ng, E.C.Y. (2012) "Forecasting US recessions with various risk factors and dynamic probit models", Journal of Macroeconomics, Vol. 34, No. 1, pp. 112-125, doi: 10.1016/j.jmacro.2011.11.001.

Nyberg, H. (2010) "Dynamic Probit Models and Financial Variables in Recession Forecasting", Journal of Forecasting, Vol. 29, No. 1-2, pp. 215-230, doi: $10.1002 /$ for. 1161 .

Pagan, A., Harding, D. (2002) "Dissecting the cycle: a methodological investigation", Journal of Monetary Economics, Vol. 49, No. 2, pp. 365-381, doi: 10.1016/S0304-3932(01)00108-8.

Pošta, V., Pikhart, Z. (2012) "The Use of the Sentiment Economic Indicator for GDP Forecasting: Evidence from EU Economies", Statistika: Statistics and Economy Journal, Vol. 49, No. 1, pp. 41-55.

Sorić, P. Škrabić, B., Čižmešija, M. (2013) "European Integration in the Light of Business and Consumer Surveys", Eastern European Economics, Vol. 51, No. 2, pp. 5-21, doi: 10.2753/EEE0012-8775510201.

Stock, J., Watson, M. (1989) "New Indexes of Coincident and Leading Indicators". In Blanchard, O., Fischer, S., eds., NBER Macroeconomic Annual 4. MIT Press, doi: $10.1086 / 654119$.

Stock, J., Watson, M. (1993) “A Procedure for Predicting Recessions with Leading Indicators: Econometric Issues and Recent Performance". In Stock, J., Watson, M., eds., Business Cycles, Indicators, and Forecasting. Chicago: University of Chicago Press. 
Subeniotis, D. N., et al. (2011) "How inflation, market capitalization, industrial production and the economic sentiment indicator affect the EU-12 stock markets", European Research Studies Journal, Vol. 14, No. 1, pp. 105-120.

Tomić, B., Sesar, A. (2015) "Interdependence of industrial production index and capital market in Croatia: VAR model", Journal of Accounting and Management, Vol. 5, No. 1, pp. 17-32.

van Aarle, B., Kappler, M. (2012) "Economic sentiment shocks and fluctuations in economic activity in the euro area and the USA", Intereconomics, Vol. 47, No. 1, pp. 44-51, doi: 10.1007/s10272-012-0405-z.

Vizek, M. (2007) "Econometric Analysis of Monetary Transmission Channels in Croatia", Privredna kretanja i ekonomska politika, Vol. 16, No. 109, pp. 28-61.

Zanin, L. (2010) "The relationship between changes in the Economic Sentiment Indicator and real GDP growth: a time-varying coefficient approach", Economics Bulletin, Vol. 30, No. 1, pp. 837-846. 


\title{
Prognoziranje vjerojatnosti recesije u Hrvatskoj: je li ekonomski sentiment nedostajuća karika? ${ }^{1}$
}

\author{
Nataša Erjavec ${ }^{2}$, Petar Soriç ${ }^{3}$, Mirjana Čižmešija ${ }^{4}$
}

\begin{abstract}
Sažetak
Cilj rada je istražiti mogućnost prognoziranja recesija u Hrvatskoj uz primjenu probit modela. Autori prvo procjenjuju osnovni probit model s četiri prethodeća pokazatelja recesije (novčana masa, nezaposlenost, industrijska proizvodnja $i$ CROBEX indeks). Razmatrano je do 6 vremenskih pomaka analiziranih varijabli u specifikaciji modela, te je dobiveno nekoliko bitnih zaključaka. Prvo, burzovni indeks $i$ novčana ponuda imaju najizraženije prethodeće karakteristike $u$ hrvatskom gospodarstvu (3 pomaka su odabrana kao optimalna po informacijskim kriterijima). Drugo, dinamički model koji uključuje i pomak zavisne varijable generira značajno preciznije procjene od osnovnog statičkog modela. Treće, autori proširuju probit model indeksom ekonomskog raspoloženja, koji opet značajno doprinosi kvaliteti modela. Ovi rezultati podupiru hipotezu da psihološki faktori u značajnoj mjeri upravljaju ekonomskim ciklusima, dobivajući na značajnosti u kriznim vremenima.
\end{abstract}

Ključne riječi: prognoziranje recesije, probit regresija, indeks ekonomskog raspoloženja, ankete pouzdanja poduzeća i potrošača

JEL klasifikacija: C22, C53, E32, E60

1 Ovaj rad je financirala Hrvatska zaklada za znanost projektom br. 3858.

2 Redovita profesorica, Ekonomski fakultet, Sveučilište u Zagrebu, Trg J. F. Kenedyja 6, Zagreb, Hrvatska. Znanstveni interes: analiza vremenskih serija, ekonometrija. Tel.: +3851 2383360 . Fax: +3851233 5633.E-mail: nerjavec@efzg.hr. Osobna web stranica: www.efzg.hr/nerjavec (autorica za korespodenciju).

${ }^{3}$ Docent, Ekonomski fakultet, Sveučilište u Zagrebu, Trg J. F. Kenedyja 6, Zagreb, Hrvatska. Znanstveni interes: nelinearna analiza vremenskih nizova, ankete pouzdanja poduzeća $i$ potrošača. Tel.: +3851238 3367.Fax:+3851233 3367.E-mail: psoric@efzg.hr. Osobna web stranica: www.efzg.hr/psoric.

${ }^{4}$ Redovita profesorica, Ekonomski fakultet, Sveučilište u Zagrebu, Trg J. F. Kenedyja 6, Zagreb, Hrvatska. Znanstveni interes: poslovna prognostika, ankete pouzdanja poduzeća i potrošača. Tel.: +3851238 3304.Fax:+3851233 3304.E-mail: mcizmesija@efzg.hr. Osobna web stranica: www.efzg.hr/mcizmesija. 
Nataša Erjavec, Petar Sorić, Mirjana Čižmešija • Predicting the probability of recession... Zb. rad. Ekon. fak. Rij. • 2016 • vol. $34 \cdot$ no. $2 \cdot 555-579$

\section{Appendices}



Nataša Erjavec, Petar Sorić, Mirjana Čižmešija • Predicting the probability of recession...

Table A1: Data set description

\begin{tabular}{|l|l|c|r|r|r|r|}
\hline Variable & \multicolumn{1}{|c|}{ Source } & Time span & \multicolumn{1}{c|}{$\min$} & \multicolumn{1}{c|}{$\max$} & \multicolumn{1}{c|}{ mean } & \multicolumn{1}{c|}{ st. dev. } \\
\hline IND & Eurostat & $2000 \mathrm{M} 01-2015 \mathrm{M} 12$ & 65,4140 & 124,0288 & 99,0901 & 14,2331 \\
\hline LM1 & IMF IFS & $2000 \mathrm{M} 01-2015 \mathrm{M} 12$ & 23,4102 & 24,9877 & 24,4518 & 0,3636 \\
\hline STOCK & Thomson Reuters & $2000 \mathrm{M} 01-2015 \mathrm{M} 12$ & 768,7062 & 5345,8610 & 1945,3320 & 981,3777 \\
\hline U & Eurostat & $2000 \mathrm{M} 01-2015 \mathrm{M} 12$ & 7,8466 & 18,0493 & 13,7469 & 2,8026 \\
\hline ESI & European Commission & 2008 M05 - 2015 M12 & 76,9961 & 122,4777 & 100,0068 & 9,9803 \\
\hline
\end{tabular}

Note: $\mathrm{IMF}=$ International Monetary Fund; IFS = International Financial Statistics

Source: Authors' construction

Table A2: Estimation of the static model with one predictor

\begin{tabular}{|c|c|c|c|c|c|c|c|}
\hline \multirow{2}{*}{\multicolumn{2}{|c|}{$\begin{array}{c}\text { Predictors } \\
\mathrm{X}_{\mathrm{t}-\mathrm{k}}\end{array}$}} & \multicolumn{6}{|c|}{$\mathrm{k}$ - months lag } \\
\hline & & 1 & 2 & 3 & 4 & 5 & 6 \\
\hline \multirow{3}{*}{ IND } & $\begin{array}{l}\begin{array}{l}\text { Parameter } \\
\text { estimate }\end{array} \\
\end{array}$ & -0.0071 & -0.0004 & 0.0054 & 0.0101 & 0.0158 & $0.0201^{*}$ \\
\hline & BIC & 93.9188 & 94.4583 & 94.1237 & 93.2863 & 91.5966 & 89.8075 \\
\hline & Pseudo $\mathrm{R}^{2}$ & 0.0063 & 0.0000 & 0.0039 & 0.0137 & 0.0335 & 0.0545 \\
\hline \multirow{3}{*}{ LM1 } & $\begin{array}{l}\text { Parameter } \\
\text { estimate }\end{array}$ & $-11.0687^{* * *}$ & $-11.6667^{* * *}$ & $-12.6459^{* * *}$ & $-14.6740^{* * *}$ & $-16.3394^{* * *}$ & $-18.2048^{* * *}$ \\
\hline & BIC & 53.9857 & 53.3704 & 51.5208 & 47.3529 & 44.7839 & 42.2185 \\
\hline & Pseudo $\mathrm{R}^{2}$ & 0.4740 & 0.4812 & 0.5028 & 0.5516 & 0.5817 & 0.6118 \\
\hline \multirow{3}{*}{ STOCK } & $\begin{array}{l}\text { Parameter } \\
\text { estimate }\end{array}$ & -0.0003 & -0.0003 & -0.0003 & -0.0003 & -0.0002 & -0.0002 \\
\hline & $\mathrm{BIC}$ & 93.2750 & 93.2994 & 93.1048 & 92.6299 & 92.8825 & 93.0667 \\
\hline & Pseudo $\mathrm{R}^{2}$ & 0.0139 & 0.0136 & 0.0159 & 0.0214 & 0.0185 & 0.0163 \\
\hline \multirow{3}{*}{$\mathrm{U}$} & $\begin{array}{l}\text { Parameter } \\
\text { estimate }\end{array}$ & -0.0856 & $-0.1003^{*}$ & $-0.1134^{* *}$ & $-0.1257^{* *}$ & $-0.1350^{* *}$ & $-0.1426^{* *}$ \\
\hline & BIC & 91.1486 & 90.0127 & 88.9273 & 87.8339 & 86.9417 & 86.1070 \\
\hline & Pseudo $\mathrm{R}^{2}$ & 0.0388 & 0.0521 & 0.0648 & 0.0776 & 0.0880 & 0.0978 \\
\hline
\end{tabular}

Note: Huber-White robust standard errors. Estimate of a constant is not reported. ${ }^{*} \mathrm{p}<.1 ;{ }^{* *} \mathrm{p}<.05 ;{ }^{* * *} \mathrm{p}<.01$.

Source: Authors' calculation 
Nataša Erjavec, Petar Sorić, Mirjana Čižmešija • Predicting the probability of recession...

Table A3: Estimation of the static model: one lag of predictors and various lags of ESI

\begin{tabular}{|l|r|r|r|r|r|r|}
\hline \multicolumn{1}{|c|}{ Predictors } & \multicolumn{1}{c|}{$\mathrm{k}=1$} & $\mathrm{k}=2$ & $\mathrm{k}=3$ & \multicolumn{1}{c|}{$\mathrm{k}=4$} & \multicolumn{1}{c|}{$\mathrm{k}=5$} & $\mathrm{k}=6$ \\
\hline $\mathrm{ESI}_{\mathrm{t}-\mathrm{k}}$ & $-0.0225^{* *}$ & $-0.0410^{* *}$ & -0.0297 & -0.0052 & 0.0083 & 0.0107 \\
\hline $\mathrm{IND}_{\mathrm{t}-1}$ & -0.0525 & -0.0288 & -0.0367 & -0.0570 & $-0.0732^{* *}$ & $-0.0737^{* *}$ \\
\hline $\mathrm{LM}_{\mathrm{t}-1}$ & $-26.5108^{* * *}$ & $-35.7871^{* * *}$ & $-33.0445^{* *}$ & $-23.9265^{* * *}$ & $-20.9616^{* * *}$ & $-20.2829^{* * *}$ \\
\hline $\mathrm{STOCK}_{\mathrm{t}-1}$ & -0.0010 & 0.0003 & -0.0007 & -0.0016 & -0.0019 & -0.0019 \\
\hline $\mathrm{U}_{\mathrm{t}-1}$ & -0.0358 & 0.4231 & 0.1312 & -0.2167 & -0.3228 & -0.3305 \\
\hline & \multicolumn{7}{|c|}{ Measures of model fit } \\
\hline BIC & 49.1368 & 46.9023 & 49.1756 & 51.1426 & 51.0478 & 50.9111 \\
\hline Pseudo R & 0.7431 & 0.7692 & 0.7426 & 0.7196 & 0.7207 & 0.7223 \\
\hline Adjusted pseudo R & 0.6025 & 0.6287 & 0.6021 & 0.5790 & 0.5802 & 0.5818 \\
\hline Log likelihood & -10.9706 & -9.8534 & -10.9900 & -11.9735 & -11.9261 & -11.8577 \\
\hline chi2 & 26.8975 & 20.5930 & 15.0683 & 35.8302 & 47.0481 & 50.1444 \\
\hline
\end{tabular}

Note: Huber-White robust standard errors. Estimate of a constant is not reported.

$$
{ }^{*} \mathrm{p}<.1 \text {; }^{* *} \mathrm{p}<.05 ;{ }^{* * *} \mathrm{p}<.01 \text {. }
$$

Source: Authors' calculation

Table A4: Estimation of the static model: two lags of predictors and various lags of ESI

\begin{tabular}{|c|c|c|c|c|c|c|}
\hline Predictors & $\mathrm{k}=1$ & $\mathrm{k}=2$ & $\mathrm{k}=3$ & $\mathrm{k}=4$ & $\mathrm{k}=5$ & $\mathrm{k}=6$ \\
\hline $\mathrm{ESI}_{\mathrm{t}-\mathrm{k}}$ & $-0.0228^{* *}$ & $-0.0250^{* *}$ & $-0.0204^{* *}$ & -0.0146 & 0.0044 & 0.0109 \\
\hline $\mathrm{IND}_{\mathrm{t}-2}$ & $-0.0627^{*}$ & $-0.0602^{*}$ & -0.0543 & -0.0493 & $-0.0686^{*}$ & $-0.0768^{* *}$ \\
\hline $\mathrm{LM} 1_{\mathrm{t}-2}$ & $-27.5951^{* * *}$ & $-28.7210^{* * *}$ & $-28.9667^{* * *}$ & $-28.2533^{* * *}$ & $-22.8416^{* * *}$ & $-21.5231^{* * *}$ \\
\hline STOCK $_{t-2}$ & -0.0016 & -0.0014 & -0.0015 & -0.0017 & $-0.0022^{*}$ & $-0.0023^{*}$ \\
\hline $\mathrm{U}_{\mathrm{t}-2}$ & -0.2837 & -0.2608 & -0.2393 & -0.2650 & -0.4516 & -0.4959 \\
\hline \multicolumn{7}{|c|}{ Measures of model fit } \\
\hline $\mathrm{BIC}$ & 49.6264 & 49.1728 & 50.3418 & 51.2836 & 51.8966 & 51.6123 \\
\hline Pseudo $\mathrm{R}^{2}$ & 0.7373 & 0.7426 & 0.7290 & 0.7179 & 0.7107 & 0.7141 \\
\hline Adjusted pseudo $\mathrm{R}^{2}$ & 0.5968 & 0.6021 & 0.5884 & 0.5774 & 0.5702 & 0.5735 \\
\hline Log likelihood & -11.2154 & -10.9886 & -11.5731 & -12.0440 & -12.3505 & -12.2083 \\
\hline chi2 & 20.3406 & 19.2576 & 23.5902 & 25.7042 & 37.0496 & 44.5114 \\
\hline
\end{tabular}

Note: Huber-White robust standard errors. Estimate of a constant is not reported.

$$
{ }^{*} \mathrm{p}<.1 ;{ }^{* *} \mathrm{p}<.05 ;{ }^{* * *} \mathrm{p}<.01 \text {. }
$$

Source: Authors' calculation 
Nataša Erjavec, Petar Sorić, Mirjana Čižmešija • Predicting the probability of recession...

Table A5: Estimation of the static model: three lags of predictors and various lags of ESI

\begin{tabular}{|l|r|r|r|r|r|r|}
\hline \multicolumn{1}{|c|}{ Predictors } & \multicolumn{1}{c|}{$\mathrm{k}=1$} & $\mathrm{k}=2$ & $\mathrm{k}=3$ & $\mathrm{k}=4$ & \multicolumn{1}{c|}{$\mathrm{k}=5$} & $\mathrm{k}=6$ \\
\hline $\mathrm{ESI}_{\mathrm{t}-\mathrm{k}}$ & $-0.0221^{* *}$ & $-0.0256^{* *}$ & $-0.0170^{* *}$ & $-0.0183^{* *}$ & -0.0035 & 0.0058 \\
\hline $\mathrm{IND}_{\mathrm{t}-3}$ & -0.0321 & -0.0426 & -0.0411 & -0.0340 & -0.0399 & -0.0496 \\
\hline $\mathrm{LM}_{\mathrm{t}-3}$ & $-31.3954^{* * *}$ & $-32.9133^{* * *}$ & $-31.3520^{* * *}$ & $-33.9471^{* * *}$ & $-29.7250^{* * *}$ & $-27.5150^{* *}$ \\
\hline $\mathrm{STOCK}_{\mathrm{t}-3}$ & $-0.0029^{*}$ & $-0.0025^{*}$ & $-0.0028^{* *}$ & $-0.0028^{* *}$ & $-0.0030^{* *}$ & $-0.0031^{* *}$ \\
\hline $\mathrm{U}_{\mathrm{t}-3}$ & -0.4247 & -0.4141 & -0.5130 & -0.4745 & -0.5079 & $-0.5738^{*}$ \\
\hline & \multicolumn{7}{|c|}{ Measures of model fit } \\
\hline BIC & 46.4774 & 45.3742 & 46.7956 & 47.0025 & 47.9711 & 47.9158 \\
\hline Pseudo R & 0.7742 & 0.7871 & 0.7705 & 0.7681 & 0.7567 & 0.7574 \\
\hline Adjusted pseudo $\mathrm{R}^{2}$ & 0.6337 & 0.6466 & 0.6300 & 0.6275 & 0.6162 & 0.6168 \\
\hline Log likelihood & -9.6409 & -9.0893 & -9.8000 & -9.9035 & -10.3877 & -10.3601 \\
\hline chi2 & 20.4774 & 19.7766 & 24.4970 & 22.8219 & 28.0918 & 35.0813 \\
\hline
\end{tabular}

Note: Huber-White robust standard errors. Estimate of a constant is not reported.

$$
{ }^{*} \mathrm{p}<.1 \text {; }^{* *} \mathrm{p}<.05 \text {; }^{* * *} \mathrm{p}<.01 \text {. }
$$

Source: Authors' calculation 